$10-19-2006$

\title{
Late Holocene Lake-Level Fluctuations in Walker Lake, Nevada, USA
}

\author{
Fasong Yuan \\ Cleveland State University, f.yuan06@csuohio.edu \\ Braddock K. Linsley \\ University at Albany-State University of New York \\ Stephen S. Howe \\ University at Albany, State University of New York
}

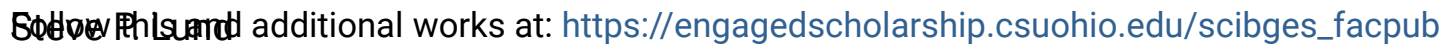

Uiversity of Southern California

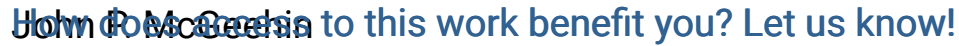

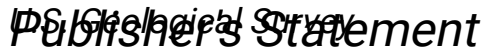

NOTICE: this is the author's version of a work that was accepted for publication in Palaeogeography, Palaeoclimatology, Palaeoecology. Changes resulting from the publishing process, such as peer review, editing, corrections, structural formatting, and other quality control mechanisms may not be reflected in this document. Changes may have been made to this work since it was submitted for publication. A definitive version was subsequently published in Palaeogeography, Palaeoclimatology, Palaeoecology, [240, 3-4, (October 19, 2006)] DOI: 10.1016/j.palaeo.2006.03.003

\section{Recommended Citation}

Yuan F, Linsley BK, Howe SS, Lund SP, McGeehin JP. 2006. Late Holocene lake-level fluctuations in Walker Lake, Nevada, USA. Palaeogeogr , Palaeoclimatol , Palaeoecol. 240(3):497-507.

This Article is brought to you for free and open access by the Biological, Geological, and Environmental Sciences Department at EngagedScholarship@CSU. It has been accepted for inclusion in Biological, Geological, and Environmental Faculty Publications by an authorized administrator of EngagedScholarship@CSU. For more information, please contact library.es@csuohio.edu. 


\title{
Late Holocene lake-level fluctuations in Walker Lake, Nevada, USA
}

\author{
Fasong Yuan ${ }^{\mathrm{a}, \mathrm{b}, *}$, Braddock K. Linsley ${ }^{\mathrm{a}}$, Stephen S. Howe ${ }^{\mathrm{a}}$, \\ Steve P. Lund ${ }^{\mathrm{c}}$, John P. McGeehin ${ }^{\mathrm{d}}$ \\ ${ }^{a}$ Department of Earth and Atmospheric Sciences, University at Albany-State University of New York, \\ 1400 Washington Avenue, Albany, NY 12222, USA \\ ${ }^{\mathrm{b}}$ Agricultural Research and Extension Center, Texas A\&M University, 1380 A\&M Circle, El Paso, TX 79927, USA \\ ${ }^{\mathrm{c}}$ Department of Earth Sciences, University of Southern California, Los Angeles, CA 90089, USA \\ ${ }^{\mathrm{d}}$ U.S. Geological Survey, 12201 Sunrise Valley Drive, Reston, VA 20192, USA
}

\section{Introduction}

Walker Lake is one of four major perennial lakes located along the western margin of the Great Basin of the western United States (Fig. 1). Today, it is a hydrologically closed, shallow $(\sim 35 \mathrm{~m})$ lake that

* Corresponding author. Agricultural Research and Extension Center, Texas A\&M University, 1380 A\&M Circle, El Paso, Texas 79927, USA. Tel.: +1 915859 9111; fax: +1 9158591078 .

E-mail address: fyuan@tamu.edu (F. Yuan). receives runoff primarily from the Walker River. The Walker River has two forks, the East Walker River and the West Walker River. The two forks receive snowmelt from the Sierra Nevada where winter precipitation is associated with the mean position of the polar jet stream (Riehl et al., 1954; Horn and Bryson, 1960; Ware and Thomson, 2000). Changes in the discharge of the Walker River and lake evaporation rate are the primary factors that govern the water balance of Walker Lake. On interannual timescales, the elevation of the surface of Walker Lake has 


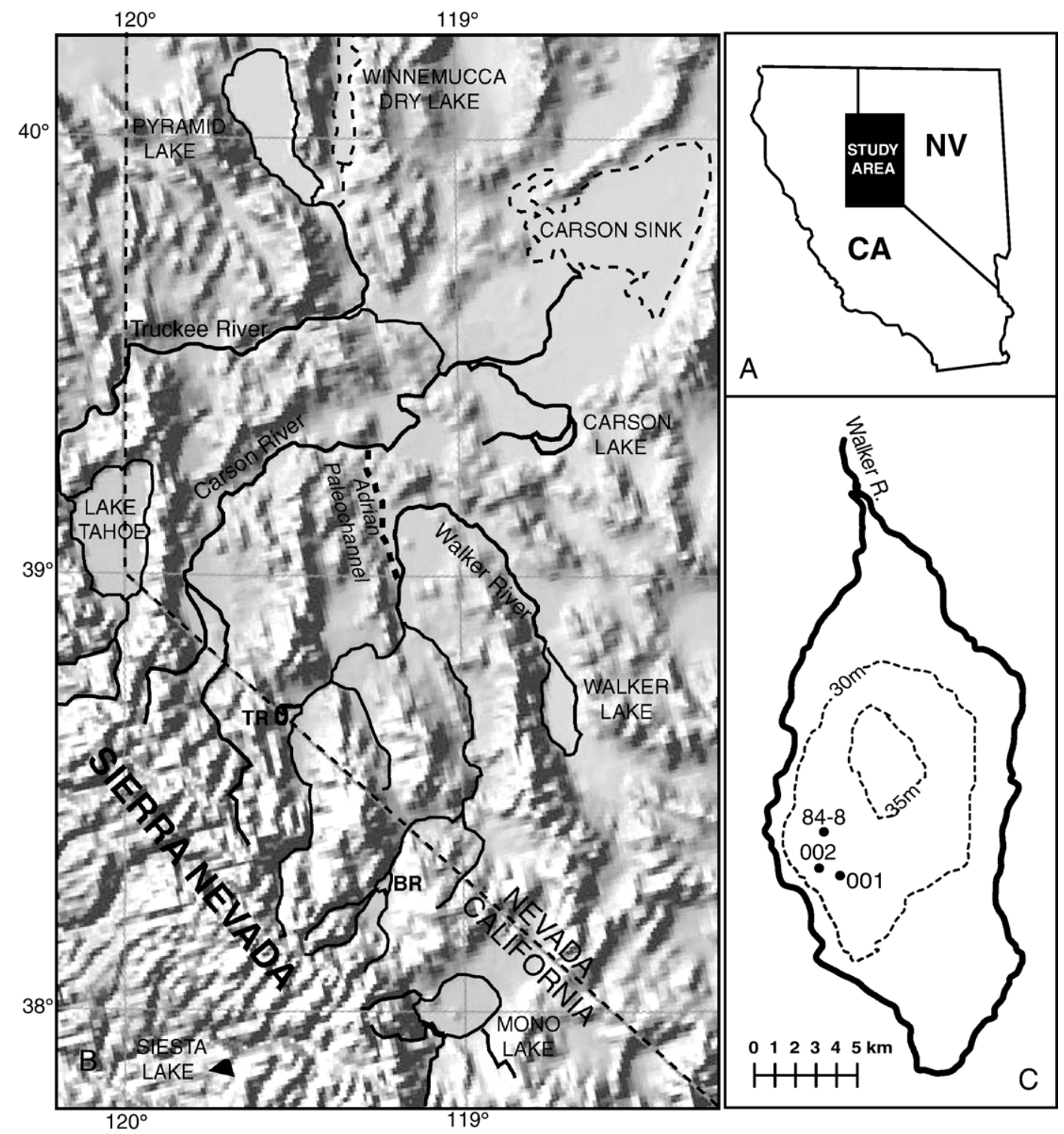

Fig. 1. Site location maps showing relevant information. (A) Index map showing the study area in the western Great Basin. (B) Shaded relief map showing the drainage basins discussed in the text. (C) Bathymetric map of Walker Lake with the location of the core sites (Benson, 1988). Prefix WLC is omitted from the core number. Boxcore WLB003C (not shown here) was retrieved from nearly the same location as piston core WLC002.

fluctuated over several meters during the last two decades. In the 20th century, this interannual variability is superimposed on a $\sim 40 \mathrm{~m}$ drop in the lake-level caused by upstream water diversion for irrigation that began in the early 1900s (Benson and Leach, 1979).

The lake-level history of Walker Lake has been the subject of investigation since the early study of Russell (1885). Hutchinson (1937) first proposed that Walker Lake desiccated during the post-Lahontan time, whereas Antevs (1952) argued that the modern Walker Lake did not form until about 1100 years B.P. based on a sim- plified salt-balance calculation. Analyses of downcore diatom concentrations (Bradbury, 1987) suggested that Walker Lake desiccated twice during the last 5000 years and that the last desiccation occurred between 2500 and 2000 years B.P. Benson et al. (1991), using a multiproxy approach, concluded that Walker Lake probably desiccated between 5300 and 4800 years B.P. and between 2700 and 2100 years B.P. These studies provide important baseline information regarding the late Holocene fluctuations of Walker Lake. However, it is debatable whether the Walker Lake desiccations were caused 
by geomorphic or climatic changes. On the basis of fish species living in Walker Lake before 1940, Benson et al. (1991) proposed that the last saline shallow-lake episode ( 2500 to 2000 years B.P.) was caused by the diversion of the Walker River, whilst Bradbury (1987) argued that it was due to climatic changes.

Today, Walker Lake is alkaline $(\mathrm{pH}>9)$, saline (salinity $\approx 12 \%$ ), and monomictic (Cooper and Koch, 1984; Beutel et al., 2001). Surface water temperature ranges from $6.0{ }^{\circ} \mathrm{C}$ in winter to $22.5{ }^{\circ} \mathrm{C}$ in summer with an annual mean temperature of $14.5^{\circ} \mathrm{C}$, and bottom water temperature ranges from $6.0^{\circ} \mathrm{C}$ in winter to $9.5^{\circ} \mathrm{C}$ in summer with an annual average of $8.3^{\circ} \mathrm{C}$ (Benson and Spencer, 1983; Cooper and Koch, 1984). Typically, the lake overturn takes place after December and lasts until April or early May (Koch et al., 1979; Benson and Paillet, 2002). Surface water temperature begins to rise in May and the lake stratifies by early summer. Most of the inorganic $\mathrm{CaCO}_{3}$ precipitates during late summer and/or early fall when water temperature exceeds $22{ }^{\circ} \mathrm{C}$ (Galat and Jacobson, 1985; Benson et al., 1991).

Changes in downcore carbonate $\delta^{18} \mathrm{O}$ are closely linked to changes in the lake volume (Benson et al., 1991; Yuan et al., 2004). When the hydrologic balance is positive, the lake-level increases and the lake-water $\delta^{18} \mathrm{O}$ decreases, and vice versa. The $\delta^{18} \mathrm{O}$ of precipitated carbonate reflects variations in the lake's hydrologic balance and water temperature. Changes in water temperature affect isotopic fractionation between water vapor and lake water and between the carbonate precipitate and lake water. For every $1{ }^{\circ} \mathrm{C}$ increase in water temperature there is a corresponding $\sim 0.1 \%$ increase in the $\delta^{18} \mathrm{O}$ value of water vapor (Benson and Paillet, 2002) and a $0.21 \%$ decrease in the $\delta^{18} \mathrm{O}$ value of precipitated carbonate (O'Neil et al., 1969). However, the $\delta^{18} \mathrm{O}$ variations induced by temperature change tend to be negligible compared to those induced by relatively large hydrologic variability in the Great Basin lakes (Benson et al., 2002, 2003; Yuan et al., 2004). Hydrologic and isotopic-balance modeling that used Pyramid Lake and Walker Lake as examples (Benson and Paillet, 2002) indicated that the overall shapes of the lake volume/level and $\delta^{18} \mathrm{O}$ records were similar and that the minima and maxima of the simulated $\delta{ }^{18} \mathrm{O}$ curve are nearly coeval with the maxima and minima in the lake volume and level curves.

Total inorganic carbon (TIC) is a useful indicator of abrupt lake-level change (Benson et al., 1996b, 1997). The TIC concentration is determined by the difference between carbonate precipitation and siliciclastic dilution of the carbonate fraction. The amount of carbonate precipitate is related to the amount of dissolved calcium input from the Walker River, which is essentially a linear function of discharge (Benson et al., 1991), whereas the mass of siliciclastic material input is likely an exponential function of discharge (Benson et al., 2002). Like $\delta^{18} \mathrm{O}$, the TIC usually decreases when the discharge increases. Magnetic susceptibility $(\chi)$ also is indicative of the lake-level dynamics (Thompson et al., 1975; Benson et al., 1991, 2002; Kirby et al., 2004). The $\chi$ of lake sediments can also vary with water depth (Thompson, 1973; Benson et al., 1991, 2002). Most of the magnetic minerals are dense and are preferentially retained in shallow-water environments (Benson et al., 2002). In deeper lake settings, however, higher streamflow can increase sediment load, allowing the transport of denser magnetic-bearing materials to deep-water sites (Kirby et al., 2004). Thus, an increase in $\chi$ in deep-water sites may indicate either a low-lake stage or an abrupt increase in streamflow discharge.

$\delta^{18} \mathrm{O}$ measurements of sediments from Walker Lake have been previously calibrated and compared with other paleoclimate records spanning the last 1200 years (Yuan et al., 2004). In this paper, we extend the high-resolution sediment record from Walker Lake back to 2700 years B.P and use measurements of $\chi$, TIC and $\delta^{18} \mathrm{O}$ to reconstruct the lake-level history for that time period, particularly to evaluate the possible causes that led to the lowstand of Walker Lake between 2500 and 2000 years B.P. by comparison to other paleoclimate records from adjacent lakes in this region.

\section{Methods}

\subsection{Core acquisition, magnetic susceptibility measurement, and sample preparation}

As discussed in Yuan et al. (2004), two piston cores (WLC001 and WLC002) plus one boxcore (WLB003C) were collected in Walker Lake in June 2000 (Fig. 1). Measurements of $\chi$ were performed every $2 \mathrm{~cm}$. The two piston cores can be stratigraphically correlated based on their lithology and $\chi$ records (Yuan et al., 2004), which allows the creation of a continuous, composite 2700-year sediment record from Walker Lake. The two piston cores were split lengthwise, described, and one half of each core was sampled at $1 \mathrm{~cm}$ increments. The boxcore was extruded vertically and sampled at $0.5 \mathrm{~cm}$ increments. Each sample was mixed with deionized water, shaken and centrifuged for $15 \mathrm{~min}$ at 20,000 rpm using an International ${ }^{\circledR}$ Centrifuge (Model CS). After centrifugation, the electrical conductivity of the supernatant was measured and the supernatant decanted. This procedure was repeated until the electrical conductivity was less than $3 \times$ that of tap water at the University at Albany- 
State University of New York. Washed samples were oven-dried at $60^{\circ} \mathrm{C}$ and then homogenized with a mortar and pestle (Benson et al., 2002). Sediment powder was soaked in $2.6 \% \mathrm{NaClO}$ for $6-8 \mathrm{~h}$ to remove organic matter, vacuum filtered with Whatman glass microfibre filters $(1.6 \mu \mathrm{m})$, rinsed with deionized water at least five times, and oven dried at $60{ }^{\circ} \mathrm{C}$ prior to isotopic analyses (Benson et al., 1996a). Ostracode shells (L. ceriotuber$o s a$ ) from the boxcore were handpicked, washed with deionized water, and oven dried at $60{ }^{\circ} \mathrm{C}$ overnight. Additionally, ostracode shells (L. ceriotuberosa) from an old core (WLC84-8) were prepared through an early project (Benson et al., 1991).

\subsection{Measurements of TIC and $\delta^{18} \mathrm{O}$}

The TIC was determined through coulometric analysis of $\mathrm{CO}_{2}$ produced after acidifying sediment samples with $2 \mathrm{~N} \mathrm{HClO}_{4}$ (Engleman et al., 1985). Oxygen isotopic analyses were conducted on a Micromass Optima gassource mass spectrometer with a MultiPrep automated sample preparation device. The isotopic results, calibrated against NBS-19, are reported in the delta $\left(\delta^{18} \mathrm{O}\right)^{1}$ notation as per mil (\%o) deviations relative to the Vienna Pee Dee Belemnite (VPDB) standard.

$\delta \% o=\left[\left(R_{\text {sample }} / R_{\text {standard }}\right)-1\right] \times 1000$

where $R$ is the $\left({ }^{18} \mathrm{O}:{ }^{16} \mathrm{O}\right)$ ratio. The standard deviation $\quad(1$ $-\sigma)$ of 87 analyses of NBS-19 $\delta^{18} \mathrm{O}$ was better than $0.04 \%$. Based on the analysis of 59 replicate samples, sample reproducibility was $1.68 \%$ in terms of mean relative error.

\subsection{Radiocarbon analysis}

Three bulk samples from WLC001 and nine from WLC002 were processed at the Radiocarbon $\left({ }^{14} \mathrm{C}\right) \mathrm{Lab}-$ oratory at the U.S. Geological Survey, Reston, Virginia. Radiocarbon ages of the total organic carbon (TOC) fraction were determined at the Center of Accelerator Mass Spectrometry (CAMS), Lawrence Livermore National Laboratory (LLNL), Livermore, California.

\subsection{Estimate of the reservoir effect}

The history of lake volume change over the last century has been well documented (Benson, 1988). This

\footnotetext{
${ }^{1}$ In this paper, $\delta^{18} \mathrm{O}$ implicitly stands for oxygen isotope composition of the TIC fraction of sediments.
}

instrumental-based lake volume change correlates well with the derivative of $\delta^{18} \mathrm{O}$ with respect to the depth in the top part of core WLC002 (Fig. 2). The correlation between the two records allows us to estimate the calendar age of the sediments at a depth of $40 \mathrm{~cm}$ in core WLC002 to be $\sim 1900$ AD (Table 1). In addition, a comparison of $\delta^{18} \mathrm{O}$ records from cores WLC002 and WLB003C (Fig. 3) indicates that the topmost sediment loss of core WLC002 is trivial because the sedimentwater interface was retained in core WLB003C.

Following the correction for the higher sedimentation rates in core WLC001 based on the magnetic susceptibility data (Yuan et al., 2004), radiocarbon ages for WLC001 and WLC002 are consistent (Fig. 4). The sedimentation rate of the upper section of core WLC002 is apparently higher than that of the lower section (depth $>335 \mathrm{~cm}$ ). Regression on the upper 8 points of core WLC002 yields a linear relation (Fig. 4). A nonzero intercept (i.e., the interpolated zero-depth age of $285{ }^{14} \mathrm{C}$ years) is due to the reservoir effect of Walker Lake because it contains ${ }^{14} \mathrm{C}$-free carbon from weathering of carbonate-bearing formations. Modern organic materials from Walker Lake also have been found to display a 300 year reservoir effect (Broecker and Walton, 1959). In this paper, we elect to use the Broecker and Walton's (1959) estimation for ${ }^{14} \mathrm{C}$ age corrections (300 years) and calibrations (Table 1$)$.

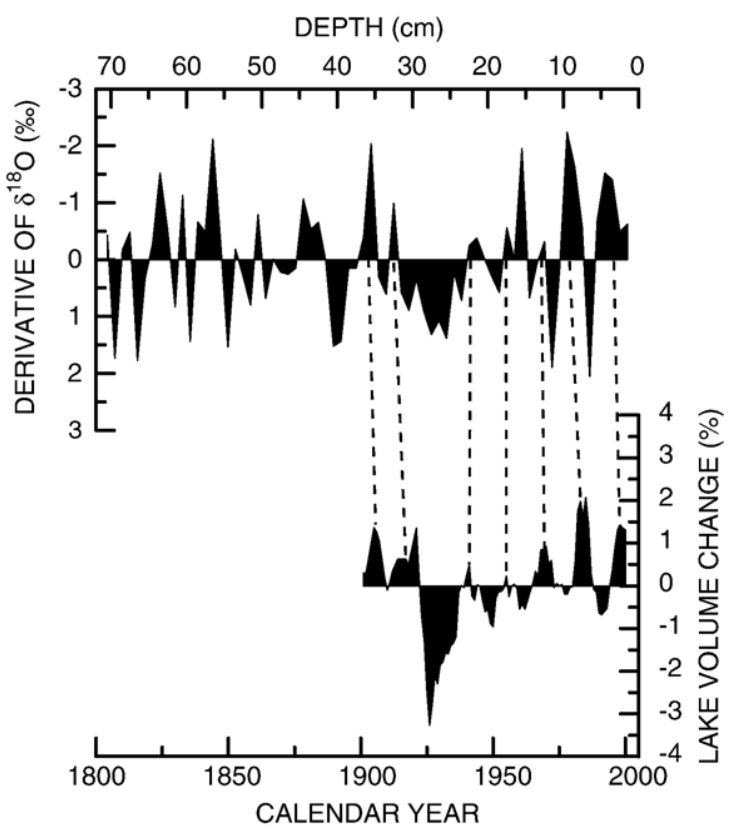

Fig. 2. Comparison of the instrumental-based Walker Lake volume change data with the derivative of $\delta^{18} \mathrm{O}$ with respect to depth (every $1 \mathrm{~cm}$ ) in core WLC002. The lake volume data were taken from Benson (1988) and smoothed using a 5-year moving average. Dashed lines denote the probable associations between the two records. 
Table 1

Radiocarbon dates from Walker Lake

\begin{tabular}{|c|c|c|c|c|c|c|c|}
\hline Core \# & Depth $(\mathrm{cm})$ & CAMS lab \# & $\begin{array}{l}\text { Radiocarbon }{ }^{a} \text { age } \\
\left({ }^{14} \mathrm{C} \text { years } \mathrm{BP}\right)\end{array}$ & Error ( \pm year) & $\begin{array}{l}\text { Calibrated age } \\
(\text { cal years BP) }\end{array}$ & Error $^{c}$ (-year) & Error $(+$ year $)$ \\
\hline \multicolumn{8}{|c|}{ WLC001 } \\
\hline & 106 & 87136 & 640 & 35 & 370 & 61 & 109 \\
\hline & 202 & 87137 & 965 & 35 & 580 & 24 & 89 \\
\hline & 327 & 87138 & 2050 & 45 & 1660 & 116 & 155 \\
\hline \multicolumn{8}{|c|}{ WLC002 } \\
\hline & 40 & 87139 & 345 & 35 & 50 & 55 & 208 \\
\hline & 67 & 87140 & 455 & 35 & 200 & 200 & 85 \\
\hline & 86.5 & 87141 & 645 & 35 & 350 & 40 & 133 \\
\hline & 137.5 & 87142 & 675 & 35 & 460 & 143 & 47 \\
\hline & 198.5 & 87143 & 1005 & 35 & 660 & 100 & 45 \\
\hline & 244.5 & 87144 & 1020 & 40 & 670 & 107 & 59 \\
\hline & 269.5 & 87145 & 1050 & 45 & 680 & 112 & 79 \\
\hline & 335.5 & 87146 & 1305 & 35 & 940 & 148 & 33 \\
\hline & 454.5 & 87147 & 2680 & 35 & 2440 & 103 & 267 \\
\hline
\end{tabular}

a Total organic carbon fraction of the samples was used for the radiocarbon dating analyses.

${ }^{\mathrm{b}}$ Calendar ages were estimated through the computer program CALIB 4.4 (Stuiver and Reimer, 1993) and a reservoir correction of 300 years (Broecker and Walton, 1959) was applied.

c $2-\sigma$ error was considered.

\subsection{Age model}

The radiocarbon dates were converted to calendar ages using the computer program CALIB 4.4 (Stuiver

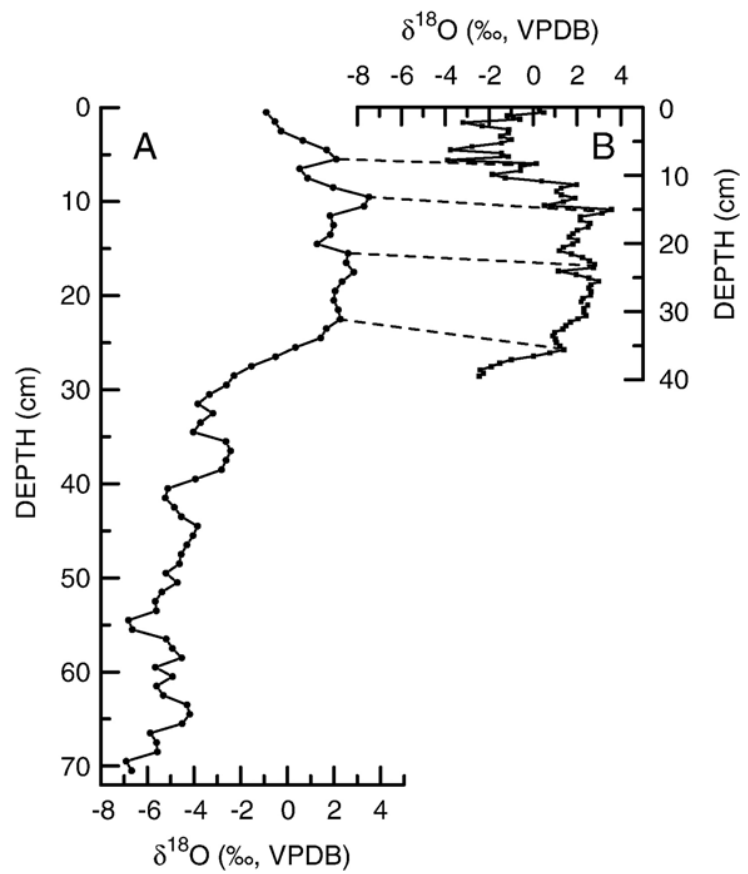

Fig. 3. Correlation of the $\delta^{18} \mathrm{O}$ records from core WLC002 (A) and WLB003C (B). Dashed lines indicate the suggested tie points between the two records. and Reimer, 1993). The calibrated ages are the most probable values constrained by a $2-\sigma$ error range (Table 1). As most of the $\chi$, TIC and $\delta^{18} \mathrm{O}$ records are derived from core WLC002, the age model described here is for core WLC002. The age model indicates a large increase in sediment accumulation rate beginning

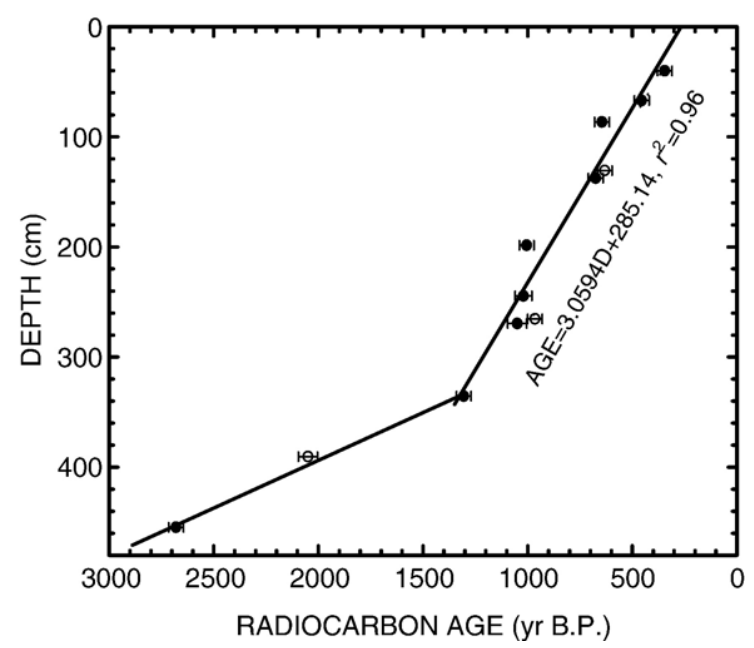

Fig. 4. Plot of the radiocarbon ages vs. depth for cores WLC001 (open circles) and WLC002 (filled circles). Numbers on the $y$-axis correspond to the depth from the sediment-water interface in core WLC002. Given that the sedimentation rates differ between the two cores, the depth of core WLC001 was converted to the corresponding depth in core WLC002 using the lithologic and magnetic susceptibility correlations (Yuan et al., 2004). Regression on the topmost 8 points from core WLC002 is represented by a linear equation. 


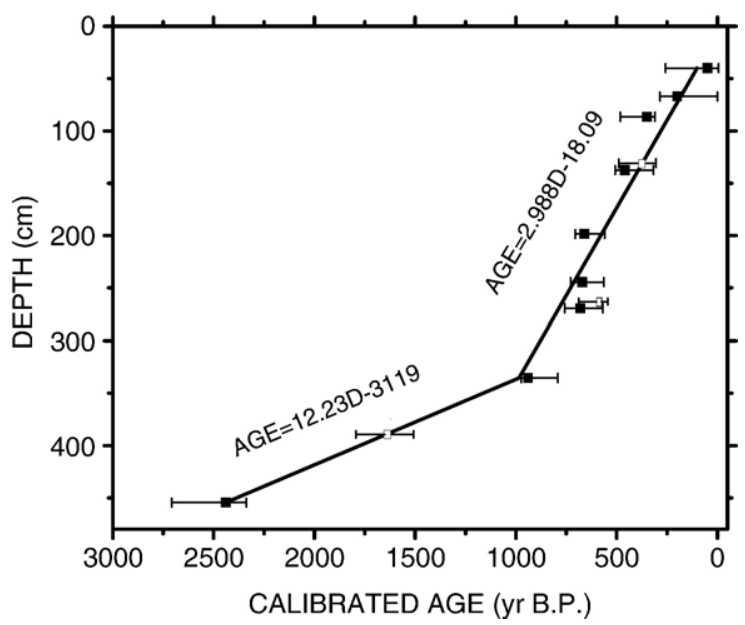

Fig. 5. Plot of the calibrated radiocarbon ages vs. depth for cores WLC002 (filled squares) and WLC001 (open squares). Individual error bars indicate $2-\sigma$ uncertainty in Table 1 . Because the sediment accumulation rate increases significantly at depth $\sim 335 \mathrm{~cm}$, two linear equations are derived through linear regression.

at $\sim 900$ years B.P. (Fig. 5). The upper eight dates plus the topmost age constraint (assumed to be modern) were regressed to determine the age model of the upper part of the core. The age model was further refined through the removal of two radiocarbon dates that are one standard deviation $(1-\sigma)$ off the regression line. The age model for the lower parts of the core was constrained using the three dates available.

\section{Results}

\subsection{Lithostratigraphy and magnetic susceptibility $(\chi)$}

The sediments are composed of massive clay deposits that are occasionally interbedded with thin $(<1 \mathrm{~cm}$ ) layers of silt (Fig. 6A). There is a $5 \mathrm{~cm}$ banded, well-sorted, sand layer containing fine micas at a depth of $250 \mathrm{~cm}$. Thin layers of silt between depths 80 $280 \mathrm{~cm}$ are associated with the maxima in $\chi$.

The composite $\chi$ record exhibits large amplitude variations at three depth intervals $(90-130 \mathrm{~cm}, 210$ $280 \mathrm{~cm}$, and $>360 \mathrm{~cm}$ ) (Fig. 6B). It is worth noting that most of the $\chi$ maxima coincide with the minima in the $\mathrm{TIC}$ and $\delta^{18} \mathrm{O}$.

\subsection{TIC measurements}

The TIC data (Fig. 6C) display large variations ranging from a trace to $32 \% \mathrm{CaCO}_{3}$. An increase in the

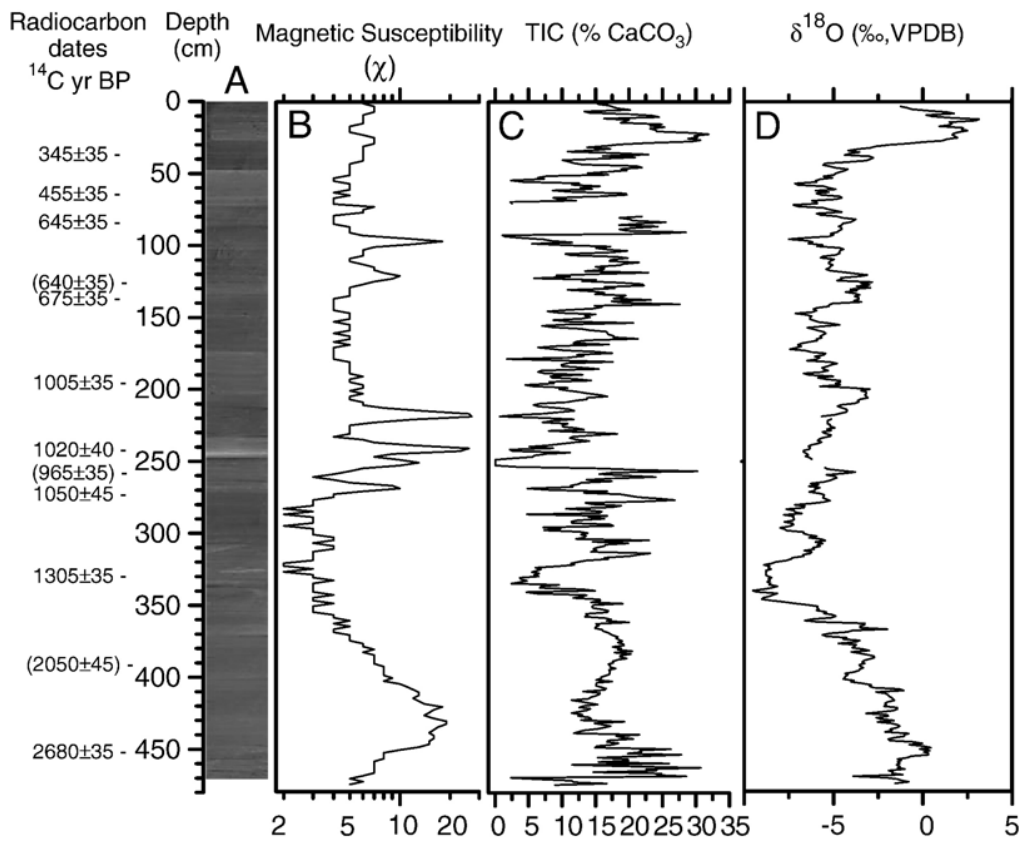

Fig. 6. Radiocarbon dated stratigraphy of the lithology, magnetic susceptibility $(\chi)$, TIC, and oxygen isotopes. (A) Spliced core photographic image of the $475 \mathrm{~cm}$ piston core from Walker Lake. (B) Spliced magnetic susceptibility $(\chi)$ record. (C) Total inorganic carbon (TIC). (D) Spliced $\delta^{18} \mathrm{O}$ record. Note that 4 points of magnetic susceptibility data and 8 points of $\delta^{18} \mathrm{O}$ data are taken from core WLC001 to splice across the coring gap of core WLC002 (Yuan et al., 2004). Thin bars following the ages indicate the approximate position of each date. Numbers in parenthesis are derived from core WLC001. 
TIC at $30 \mathrm{~cm}$ is probably due to a reduction in siliciclastic material input beginning in early 1900s. Most of the maxima in $\chi$ coincide with the TIC minima, indicating the dilution of TIC by siliciclastic material.

\subsection{Oxygen isotopes}

The composite record of downcore variations in $\delta^{18} \mathrm{O}$ is shown in Fig. 6D. The Walker Lake sediments are characterized by relatively larger amplitude variations in $\delta^{18} \mathrm{O}$ compared to other lakes located along the western margin of the Great Basin (Benson et al., 1996a; Yuan et al., 2004). The upper $350 \mathrm{~cm}$ (last 1200 years) of the $\delta{ }^{18} \mathrm{O}$ series displays distinctive features linked to changes in the hydrologic balance of the lake (Yuan et al., 2004). The sediments have ${ }^{18} \mathrm{O}$-enriched signatures below $350 \mathrm{~cm}$ and are ${ }^{18} \mathrm{O}$-depleted between 320 and $350 \mathrm{~cm}$. Above this interval, the $\delta^{18} \mathrm{O}$ becomes progressively ${ }^{18} \mathrm{O}$-enriched, reaching a local maximum at $200 \mathrm{~cm}$. At a depth of $40 \mathrm{~cm}$, an anthropogenically induced drop in the lake-level drives the $\delta^{18} \mathrm{O}$ to an unprecendentedly high level $\left(\delta^{18} \mathrm{O}>2.5 \%\right)$.

L. ceriotuberosa is the only abundant ostracode that lives at the lake sediment-water interface today (Bradbury, 1987; Bradbury et al., 1989). The $\delta^{18} \mathrm{O}$ records of the L. ceriotuberosa shells $\left(\delta^{18} \mathrm{O}_{\mathrm{OST}}\right)$ and TIC fraction $\left(\delta^{18} \mathrm{O}_{\mathrm{TIC}}\right)$ from cores WLB003C and WLC84-8 are shown in Figs. 7 and 8 . The two $\delta^{18} \mathrm{O}_{\mathrm{OST}}$ records have

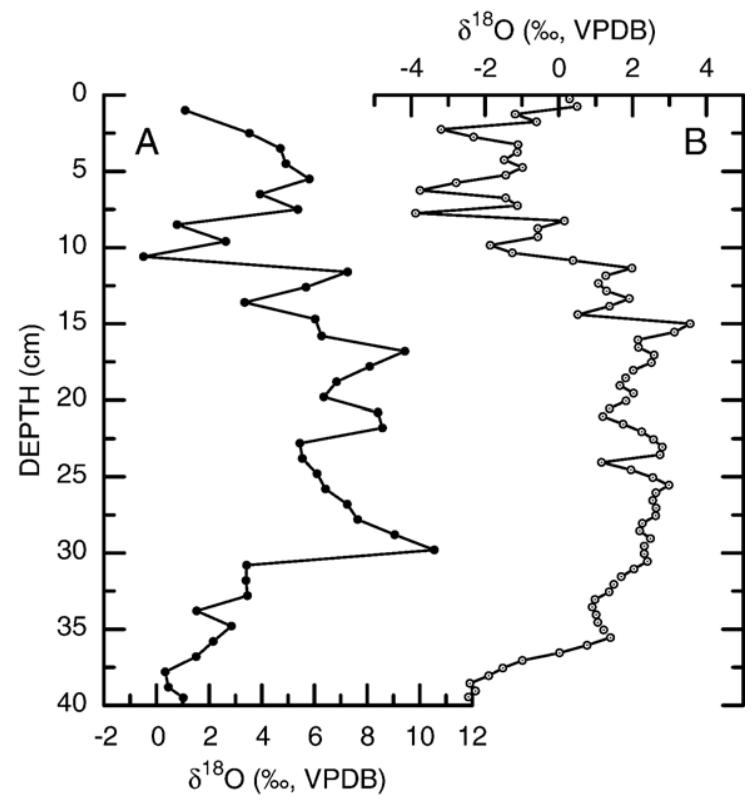

Fig. 7. Comparison of the $\delta^{18} \mathrm{O}$ results of ostracode shells (A) and bulk inorganic carbonate sediments (B) from core WLB003C. Note that the sample spacing for the ostracode $\delta^{18} \mathrm{O}$ record is approximately $1 \mathrm{~cm}$.

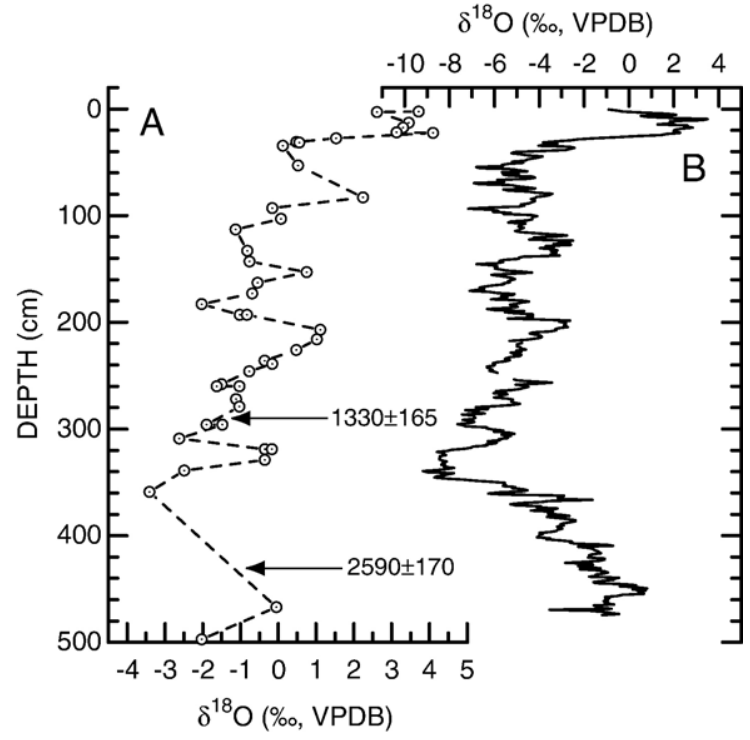

Fig. 8. Comparison of the $\delta^{18} \mathrm{O}$ records of ostracode shells from core WLC84-8 (A) and bulk inorganic carbonate sediments from cores WLC001 and WLC002 (B). Approximately half of the ostracode $\delta^{18} \mathrm{O}$ data are taken from Benson et al. (1991); the new data are the analyses of ostracode shells performed at the University at Albany in January 2000. Radiocarbon dates associated with the old core are taken from Benson (1988).

relatively low sampling resolution, but show overall similarity with the two $\delta^{18} \mathrm{O}_{\mathrm{TIC}}$ records. This indicates that the changes in lake-water $\delta^{18} \mathrm{O}$ due to lake-level fluctuations are recorded in downcore carbonate sediments. $\delta^{18} \mathrm{O}_{\mathrm{OST}}$ is on average $4 \%$ higher than $\delta^{18} \mathrm{O}_{\mathrm{TIC}}$, but tends to be more "spiky" in many intervals (Fig. 7). The $4 \%$ difference in $\delta{ }^{18} \mathrm{O}$ is likely due to a combination of the vital effect on $L$. ceriotuberosa and the temperature difference between surface and bottom waters (Benson et al., 1991). Additionally, radiocarbon ages derived from core WLC84-8 (Benson, 1988) are consistent with those from core WLC002 (Fig. 8).

\section{Discussion}

The $\delta^{18} \mathrm{O}$ record from Walker Lake shows distinctive features that reflect changes in its hydrologic balance over the last 2700 years (Fig. 9). This late Holocene record may be separated into five distinct periods (labeled 1-5) based on the long-term variability in $\chi$, TIC, and $\delta^{18} \mathrm{O}:(1)$ an early low lake period $(\sim 2700-$ 2400 years B.P.), (2) a period during which lake-level increases (2400-1000 years B.P.), (3) a period during which lake-level falls (1000-600 years B.P.), (4) a relatively wet period during which there are at least two major lake-level oscillations (600-100 years B.P.), and 


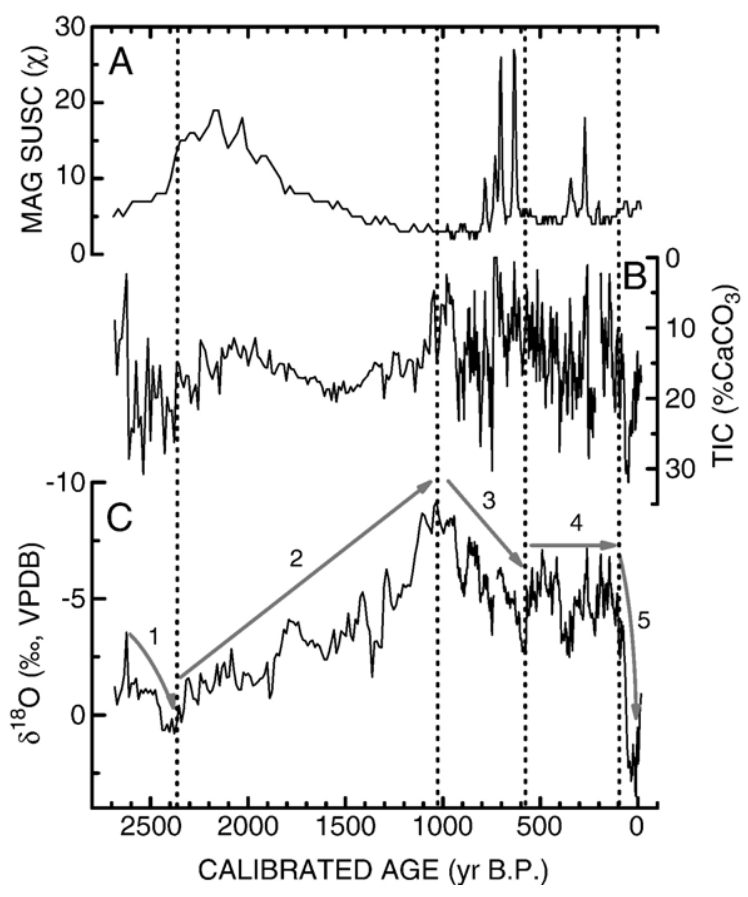

Fig. 9. Late Holocene sediment record from Walker Lake. (A) Magnetic susceptibility $(\chi)$. (B) TIC. (C) Oxygen isotope compositions $\left(\delta^{18} \mathrm{O}\right)$. Vertical dashed lines separate the five hydrologic regimes (numbered 1 to 5) with distinctive isotopic signatures. Gray arrows highlight the overall $\delta^{18} \mathrm{O}$ trends.

(5) a historical period during which lake-level falls rapidly due to upstream water diversions $(<100$ years B.P.). The early low lake period (Period 1) is characterized by progressive increases in $\delta^{18} \mathrm{O}$, TIC, and $\chi$ values, with relatively large fluctuations in the TIC. We interpret the data to indicate that during Period 1 the level of Walker Lake was very low. There is a rapid transition in the three lake-level proxy data at the end of Period 1, signaling the onset of increased lake size. The multicentury scale positive excursion of $\chi$ is likely associated with both lowstands and high-flow periods, both of which increase the flux of detrital magnetite-bearing materials to the core sites during the early intervals of Period 2. In contrast, the low $\chi$ values in the later intervals of Period 2 suggest that lake-level is relatively high, limiting the transport of dense detrital magnetic materials to the core sites. A millennial-scale decreasing (or negative) trend of $\delta^{18} \mathrm{O}$ within Period 2 further suggests the persistence of relatively wet conditions or positive water balance of Walker Lake (Fig. 9C). The TIC record exhibits considerably lower variability in this period, implying an increased buffering of the calcium reservoir due to increased lake volume. During the Medieval Warm Period (MWP; Period 3, 1000600 years B.P.), Walker Lake, like other lakes (e.g.,
Mono Lake and Pyramid Lake) in this region (Stine, 1990; Benson et al., 2002), experienced a prolonged dry period, as inferred from progressive increases in the $\delta{ }^{18} \mathrm{O}$ values. Note that three relatively high $\delta^{18} \mathrm{O}$ intervals that indicate times of relative dryness are apparent in this part of the record. The high $\chi$ values near the end of this period indicate times of low lake-level. We suggest that the transport of dense magnetite bearing materials to the core sites occurred during floods. Period 4 coincides with the Little Ice Age (LIA; 600100 years B.P.) and is relatively wet given its low values of the $\delta^{18} \mathrm{O}$. At least one severe drought occurred between 300 and 400 years B.P. After $\sim 100$ years B.P., the lake-level history was severely affected by human activities through a considerable reduction in streamflow discharge to the lake resulting from increasing irrigation water diversions and upstream impoundments starting in the early 1900s (Benson and Leach, 1979). This anthropogenically induced lake-level lowering was clearly recorded in downcore sediment proxies that display rapid increases in the TIC and $\delta{ }^{18} \mathrm{O}$.

To examine the possible causes of changes in the level of Walker Lake over the last 2700 years, we compare the Walker Lake $\delta^{18} \mathrm{O}$ record with a $\delta^{18} \mathrm{O}$ record from Pyramid Lake (Benson et al., 2002) and a charcoal fragment record from Siesta Lake (Brunelle and Anderson, 2003) (Fig. 10). As discussed in Yuan et al. (2004), both Walker Lake and Pyramid Lake have recorded several century-scale oscillations in hydrologic conditions over the last 1200 years which may be associated with the regional changes in atmospheric circulation. However, there exist some important discrepancies between the two records. For example, the Walker Lake record shows larger magnitude variations in $\delta^{18} \mathrm{O}$ partially due to the volume of Walker Lake being much smaller than that of Pyramid Lake and more sensitive to discharge variability. Moreover, the long-term trends in $\delta^{18} \mathrm{O}$ of the two lakes are mirror images of each other between 2700 and 1400 years B.P. Walker Lake experienced a decreasing (negative) trend in $\delta^{18} \mathrm{O}$, whilst Pyramid Lake experienced an increasing (positive) trend in $\delta^{18} \mathrm{O}$. The charcoal fragment record from Siesta Lake, California (Brunelle and Anderson, 2003) also suggests an overall increasing (positive) trend in fire frequency on the western flank of the Sierra Nevada during that time period (Fig. 10C). This suggests that the Sierran climate most likely experienced increasing aridity between 2700 and 1400 years B.P. The opposite long-term (millennial timescales) trends of $\delta^{18} \mathrm{O}$ are interpreted to indicate that Walker Lake was likely to be affected by non-climatic processes (e.g., river diversions and/or post-depositional sediment diagenesis). 


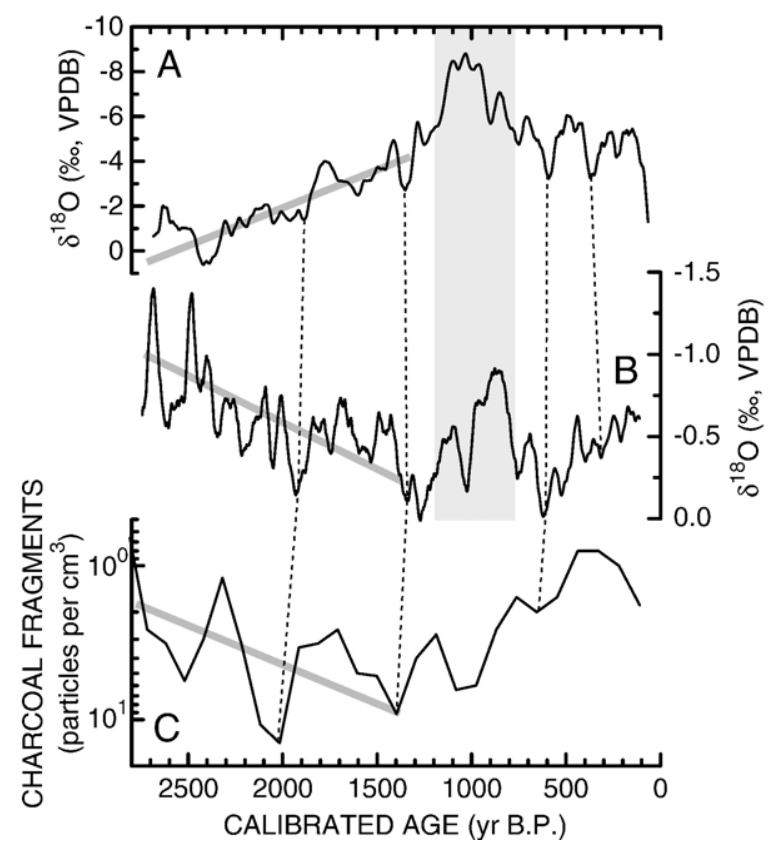

Fig. 10. Comparison of the late Holocene sediment records from Pyramid Lake, Walker Lake and Siesta Lake. (A) Walker Lake $\delta^{18} \mathrm{O}$. (B) Pyramid Lake $\delta^{18} \mathrm{O}$ (Benson et al., 2002). Note that the vertical scales for the two $\delta^{18} \mathrm{O}$ records are not same, i.e., the scale for the Pyramid Lake is expanded. To emphasize century-scale variability, raw data of the two records were extracted every 1 year using a cubic spline fitting and then smoothed through a 40-point adjacent averaging. (C) Siesta Lake charcoal record (Brunelle and Anderson, 2003). Note that charcoal fragments $(>250 \mu \mathrm{m})$ record has the lowest temporal resolution $\left(\sim 100\right.$ years $\left.\mathrm{cm}^{-1}\right)$. Thick gray lines indicate the long-term (millennial timescales) trends in the three records between 2800 and 1400 years B.P. Dashed lines indicate the probable connections between the three records. The vertical gray bar highlights the timing of significantly large negative $\delta^{18} \mathrm{O}$ excursions that occurred in Walker Lake and Pyramid Lake during the late Holocene.

It has been postulated that some geochemical processes (e.g., post-depositional recrystallization) may have altered the original isotopic composition of carbonate sediments through interactions with pore fluids (Benson et al., 1991). X-ray diffraction analysis of sediments from core WLC84-8 (Benson, 1988; Benson et al., 1991) indicates that monohydrocalcite is the dominant carbonate mineral in the upper $2 \mathrm{~m}$ core and that scalenohedral crystal crusts are present between 4 and $7.4 \mathrm{~m}$. As described in Section 3.3, the $\delta^{18} \mathrm{O}_{\mathrm{OST}}$ records from cores WLB003C and WLC84-8 show overall similar features in their corresponding $\delta^{18} \mathrm{O}_{\mathrm{TIC}}$ records. The sampling resolution of the $\delta^{18} \mathrm{O}_{\mathrm{OST}}$ record from core WLC84-8 is an order of magnitude lower than that of the $\delta^{18} \mathrm{O}_{\mathrm{TIC}}$ record from core WLC002, but both records show a concurrent decreasing (negative) trend of $\delta^{18} \mathrm{O}$ in depths between 370 and $470 \mathrm{~cm}$ (i.e., bet- ween 2700 and 1400 years B.P.) (Fig. 8). This suggests that changes in downcore $\delta^{18} \mathrm{O}$ are largely induced by changes in the lake's hydrologic balance rather than post-depositional recrystallization.

In the Walker Lake basin, Walker River diversions into the Carson Sink via the Adrian Valley have been previously suggested (King, 1993) (see Fig. 1) but the timing of the river diversions remains unknown. We hypothesize that the Walker River may have partially diverted into the Carson River drainage between 2700 and 1200 years B.P., with the amount of diversion decreasing over time. This would explain the differences between the Walker Lake and Pyramid Lake $\delta^{18} \mathrm{O}$ records in this time period. The partial Walker River diversion may have initialized during some flood periods prior to 2500 years B.P., as inferred from the two large negative $\delta^{18} \mathrm{O}$ excursions at the beginning of the Pyramid Lake record. Under this scenario, Walker Lake was very low at $\sim 2400$ years B.P. due to a temporary isolation of Walker Lake from the Walker River drainage. The subsequent lowering of the lake would have allowed the transport of denser magnetic-bearing materials into deep sites in the lake. The amount of diversion may have gradually reduced over time and ceased by 1400 years B.P. We suggest that the lower reaches of the Walker River were blocked only partially because of the persistence of coherent multidecadal to centennial timescale variability of $\delta^{18} \mathrm{O}$ in the two lake basins despite the opposed long-term secular trends in $\delta^{18} \mathrm{O}$. The geomorphic simplicity of the Adrian paleochannel also suggests the entire Walker River did not occupy the Adrian Valley for a long time (King, 1993). In addition, a diatom concentration record from Walker Lake displays "a fluctuating but consistently decreasing trend" between $\sim 3100$ and $\sim 2200$ years B.P. (Bradbury, 1987; see his Fig. 7). This appears to be inconsistent with a sudden, irrevocable diversion of the Walker River (Bradbury, 1987), but the likelihood of a partial or temporary isolation of Walker Lake during that time period cannot be ruled out.

\section{Conclusions}

The Walker Lake sediments document a continuous high-resolution record of lake-level dynamics in the late Holocene. The late Holocene history of Walker Lake is compounded by probable geomorphic changes, as inferred from the multi-basin sediment records in the region. The Walker River may have partially diverted into the Carson Sink through the Adrian paleochannel between 2700 and 1400 years B.P., with the amount of diversion decreasing over time. The integrated proxy data 
derived from downcore sediments display five main stages over the course of the late Holocene hydrologic evolution of the Walker Lake system. They are an early low stage ( $>2400$ years B.P.) that may have been due in part to a partial diversion of the Walker River into the Adrian Valley, a lake-filling period ( $2400-1000$ years B.P.) as the river progressively diverted back into Walker Lake, a lake-level lowering period during the MWP $(\sim 1000-600$ years B.P.), a relatively wet period $(\sim 600$ 100 years B.P.), and the anthropogenically induced drought period $(<100$ years B.P.).

\section{Acknowledgments}

We are indebted to L. Benson for his supervision of the core collection, thoughtful ideas and discussions, and review of an early version of this manuscript. We thank J. Smoot, A. Heyvaert and B. Richards for the field assistance in core collection, and D. Rodbell for the analytical assistance. The radiocarbon analyses were kindly supported by J. Rosenbaum of the U.S. Geological Survey. The first author wishes to acknowledge the support of the University at Albany-State University of New York. Special thanks are due to R. Harvey, K. Wickland, H. Li and one anonymous reviewer for their valuable comments and suggestions.

\section{References}

Antevs, E., 1952. Cenozoic climates of the Great Basin. Geol. Rundsch. 40 (1), 94-108.

Benson, L., 1988. Preliminary paleolimnological data for the Walker Lake Subbasin, California and Nevada. U.S. Geological Survey, Water-Resources Investigations Report 87-4258, Boulder, Colorado.

Benson, L.V., Leach, D.L., 1979. Uranium transport in the Walker River Basin, California and Nevada. J. Geochem. Explor. 11 (3), 227-248

Benson, L., Paillet, F., 2002. HIBAL: a hydrologic-isotopic-balance model for application to paleolake systems. Quat. Sci. Rev. 21 (12-13), 1521-1539.

Benson, L.V., Spencer, R.J., 1983. A hydrological reconnaissance study of the Walker River Basin, California and Nevada. U.S. Geological Survey Open-File Report, vol. 83-740, p. 53.

Benson, L.V., Meyers, P.A., Spencer, R.J., 1991. Change in the size of Walker Lake during the past 5000 years. Palaeogeogr. Palaeoclimatol. Palaeoecol. 81 (3-4), 189-214.

Benson, L., White, L.D., Rye, R., 1996a. Carbonate deposition, Pyramid Lake Subbasin, Nevada: 4. Comparison of the stable isotope values of carbonate deposits (tufas) and the Lahontan lakelevel record. Palaeogeogr. Palaeoclimatol. Palaeoecol. 122 (1-4), $45-76$.

Benson, L.V., Phillips, F.M., Rye, R.O., Burdett, J.W., Kashgarian, M., Lund, S.P., 1996b. Climatic and hydrologic oscillations in the Owens Lake Basin and adjacent Sierra Nevada, California. Science 274 (5288), 746-749.

Benson, L., Mensing, S., Burdett, J., Lund, S., Kashgarian, M., 1997. Nearly synchronous climate change in the Northern Hemisphere during the last glacial termination. Nature 388 (6639), 263-265.

Benson, L., Lund, S., Paillet, F., Smoot, J., Kester, C., Mensing, S., Meko, D., Lindström, S., Kashgarian, M., Rye, R., 2002. Holocene multidecadal and multicentennial droughts affecting Northern California and Nevada. Quat. Sci. Rev. 21 (4-6), 659-682.

Benson, L., Linsley, B., Smoot, J., Mensing, S., Lund, S., Stine, S., Sarna-Wojcicki, A., 2003. Influence of the Pacific decadal oscillation on the climate of the Sierra Nevada, California and Nevada. Quat. Res. 59 (2), 151-159.

Beutel, M.W., Horne, A.J., Roth, J.C., Barratt, N.J., 2001. Limnological effects of anthropogenic desiccation of a large, saline lake, Walker Lake, Nevada. Hydrobiologia 466, 91-105.

Bradbury, J.P., 1987. Late Holocene diatom paleolimnology of Walker Lake, Nevada. Arch. Hydrobiol., Suppl. 79 (1), 1-27.

Bradbury, J.P., Forester, R.M., Thompson, R.S., 1989. Late Quaternary paleolimnology of Walker Lake, Nevada. J. Paleolimnol. 1 (4), 249-267.

Broecker, W.S., Walton, A.F., 1959. The geochemistry of ${ }^{14} \mathrm{C}$ in freshwater systems. Geochim. Cosmochim. Acta 16, 15-38.

Brunelle, A., Anderson, R.S., 2003. Sedimentary charcoal as an indicator of late-Holocene drought in the Sierra Nevada, California, and its relevance to the future. Holocene 13 (1), 21-28.

Cooper, J.J., Koch, D.L., 1984. Limnology of a desertic terminal lake, Walker Lake, Nevada, USA. Hydrobiologia 118, 275-292.

Engleman, E.E., Jackson, L.L., Norton, D.R., 1985. Determination of carbonate carbon in geological materials by coulometric titration. Chem. Geol. 53, 125-128.

Galat, D.L., Jacobson, R.L., 1985. Recurrent aragonite precipitation in saline-alkaline Pyramid Lake, Nevada. Arch. Hydrobiol., Suppl. 105, 137-159.

Horn, L.H., Bryson, R.A., 1960. Harmonic analysis of the annual march of precipitation over the United States. Ann. Assoc. Am. Geogr. 50, 157-171.

Hutchinson, G.E., 1937. A contribution to the limnology of arid regions. Trans. Conn. Acad. Arts Sci. 33, 47-132.

King, G.Q., 1993. Late Quaternary history of the lower Walker River and its implications for the Lahontan paleolake system. Phys. Geogr. 14, 81-96.

Kirby, M.E., Poulsen, C.J., Lund, S.P., Patterson, W.P., Reidy, L., Hammond, D.E., 2004. Late Holocene lake level dynamics inferred from magnetic susceptibility and stable oxygen isotope data: Lake Elsinore, southern California (USA). J. Paleolimnol. 31, 275-293.

Koch, D.L., Cooper, J.J., Lider, E.L., Jacobson, R.L., Spencer, R.J., 1979. Investigations of Walker Lake, Nevada: dynamic ecological relationships. Desert Res. Inst. Publ., vol. 50010. University of Nevada, Reno.

O’Neil, J.R., Clayton, R.N., Mayeda, T.K., 1969. Oxygen isotopic fractionation in divalent metal carbonates. J. Chem. Phys. 51, $5547-5558$

Riehl, H., Alaka, M.A., Jordan, C.L., Renard, R.J., 1954. The jet stream. Meteorol. Monogr. 2, 23-47.

Russell, I.C., 1885. Geological History of Lake Lahontan, A Quaternary Lake of Northwestern Nevada.

Stine, S., 1990. Late Holocene fluctuations of Mono Lake, eastern California. Palaeogeogr. Palaeoclimatol. Palaeoecol. 78 (3-4), 333-381. 
Stuiver, M., Reimer, P.J., 1993. Extended ${ }^{14} \mathrm{C}$ data base and revised CALIB $3.0{ }^{14} \mathrm{C}$ age calibration program. Radiocarbon 35 (1), 215-230.

Thompson, R., 1973. Palaeolimnology and palaeomagnetism. Nature $242,182-184$.

Thompson, R., Battarbee, R.W., O’Sullivan, P.E., Oldfield, F., 1975. Magnetic susceptibility of lake sediments. Limnol. Oceanogr. 20 (5), $687-698$.
Ware, D.M., Thomson, R.E., 2000. Interannual to multidecadal timescale climate variations in the Northeast Pacific. J. Clim. 13 (18), 3209-3220.

Yuan, F., Linsley, B., Lund, S., McGeehin, J., 2004. A 1200 year record of hydrologic variability in the Sierra Nevada from sediments in Walker Lake, Nevada. Geochem. Geophys. Geosyst. $5(3), 1-13$. 